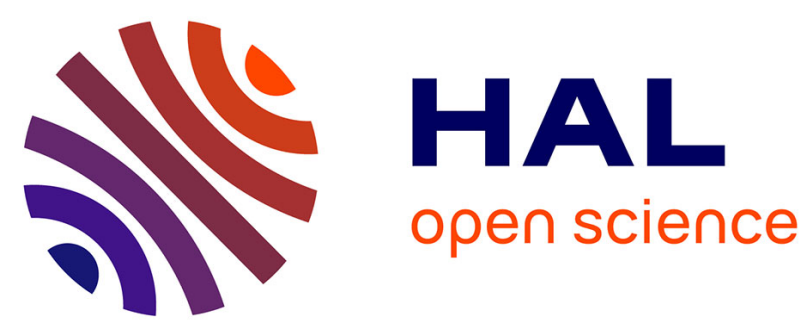

\title{
Partitioning groundwater recharge between rainfall infiltration and irrigation return flows using stable isotopes: the Crau aquifer.
}

\author{
Séraphin Pierre, Christine Vallet-Coulomb, Julio Goncalves
}

\section{To cite this version:}

Séraphin Pierre, Christine Vallet-Coulomb, Julio Goncalves. Partitioning groundwater recharge between rainfall infiltration and irrigation return flows using stable isotopes: the Crau aquifer.. Journal of Hydrology, 2016, 542, pp.241-253. 10.1016/j.jhydrol.2016.09.005 hal-01475408

\section{HAL Id: hal-01475408 \\ https://hal-amu.archives-ouvertes.fr/hal-01475408}

Submitted on 30 Apr 2019

HAL is a multi-disciplinary open access archive for the deposit and dissemination of scientific research documents, whether they are published or not. The documents may come from teaching and research institutions in France or abroad, or from public or private research centers.
L'archive ouverte pluridisciplinaire HAL, est destinée au dépôt et à la diffusion de documents scientifiques de niveau recherche, publiés ou non, émanant des établissements d'enseignement et de recherche français ou étrangers, des laboratoires publics ou privés. 


\title{
Partitioning groundwater recharge between rainfall infiltration and irrigation return flow using stable isotopes: The Crau aquifer
}

\author{
Pierre Séraphin *, Christine Vallet-Coulomb, Julio Gonçalvès \\ Aix Marseille Université, CNRS, IRD, CDF, CEREGE UM 34, 13545 Aix en Provence, France
}

\section{K E Y W O R D S}

Stable isotope

Geostatistics

Groundwater budget

Isotope mass balance

Irrigation

Crau aquifer

\begin{abstract}
A B S T R A C T
This study reports an assessment of the water budget of the Crau aquifer (Southern France), which is poorly referenced in the literature. Anthropogenically controlled by a traditional irrigation practice, this alluvial type aquifer requires a robust quantification of the groundwater mass balance in order to establish sustainable water management in the region. In view of the high isotopic contrast between exogenous irrigation waters and local precipitations, stable isotopes of water can be used as conservative tracers to deduce their contributions to the surface recharge. Extensive groundwater sampling was performed to obtain $\delta 180$ and $\delta 2 \mathrm{H}$ over the whole aquifer. Based on a new piezometric contour map, combined with an updated aquifer geometry, the isotopic data were implemented in a geostatistical approach to produce a conceptual equivalent homogeneous reservoir. This makes it possible to implement a parsimonious water and isotope mass-balance mixing model. The isotopic compositions of the two end-members were assessed, and the quantification of groundwater flows was then used to calculate the two recharge fluxes (natural and irrigation). Nearly at steady-state, the set of isotopic data treated by geostatistics gave a recharge by irrigation of $4.92 \pm 0.89 \mathrm{~m}^{3} \mathrm{~s}^{-1}$, i.e. $1109 \pm 202 \mathrm{~mm} \mathrm{yr}^{-1}$, and a natural recharge of $2.19 \pm 0.85 \mathrm{~m}^{3} \mathrm{~s}^{-1}$, i.e. $128 \pm 50 \mathrm{~mm} \mathrm{yr}^{-1}$. Thus, $69 \pm 9 \%$ of the surface recharge is caused by irrigation return flow. This study constitutes a straightforward and independent approach to assess groundwater surface recharges including uncertainties and will help to constrain future transient groundwater models of the Crau aquifer.
\end{abstract}

\section{Introduction}

Since the last century, population growth and climate change have increased the need for the preventive management of groundwater. Knowledge of the groundwater budget is a key factor in establishing sustainable exploitation of an aquifer. Because the recharge rate of an aquifer is diffuse and varies in both space and time, it is the most difficult term of a regional water balance equation to measure. Surface recharge usually comes from rainfall infiltration but can also be due to irrigation return flow in some agricultural regions.

Agricultural practices may depend on, and in turn affect, the functioning of an aquifer in various ways. While agricultural uptakes induce an obvious direct discharge, significant irrigation practices can also indirectly affect the discharge of an aquifer. Thus, raising the piezometric surface by irrigation return flow can create areas of overflow or allow some crops to reach the water table

\footnotetext{
* Corresponding author.

E-mail address: seraphin@cerege.fr (P. Séraphin).
}

directly, producing direct groundwater evapotranspiration, (Loheide et al., 2005; Tsang et al., 2014) and even induce salinization (Bouzourra et al., 2014). Conversely, as observed with the Dan Region Project in Israel (Kanarek and Michail, 1996), and in the south of Portugal (Stigter et al., 2006), an irrigation process wisely used can be a sustainable way to preserve the water table level and the quality of an aquifer.

Quantifying recharge rate and, by extension, the groundwater budget of an aquifer is often performed using a calibrated hydrogeological model. This requires parameters such as permeability and specific yield (in the case of transient simulations), and can be highly time-consuming. Alternative methods to ascertain the groundwater budget are surface watershed water budget or geochemical tracers. The latter are crucial to improve the knowledge of aquifer hydrodynamics, especially to dissociate the respective contribution of different origins of groundwater recharges, which is very difficult to obtain with conventional methods.

Stable isotopes of water $\left(\delta^{18} \mathrm{O}, \delta^{2} \mathrm{H}\right)$ have been used since the pioneering work of Craig (1961) and Dansgaard (1964) to trace 
the water cycle. Unlike many physical measurements generally used for implementing hydrogeological models, stable isotopes of water can monitor the hydrologic behavior of an entire reservoir (Gat and Gonfiantini, 1981). In the absence of fractionation processes due to evaporation or condensation, stable isotopes constitute a fully conservative tracer, making it possible to determine mixing fractions of different water masses involved in groundwater fluxes (Darling et al., 1996; Gattacceca et al., 2009; Gonçalvès et al., 2015; Guglielmi et al., 1998; Huneau et al., 2011; Kim et al., 2003; McGuire et al., 2002; Williams, 1997) and to compute e.g., the amount of artificial recharge of an aquifer (Liu et al., 2014; Ma and Spalding, 1996; Plöthner and Geyh, 1991).

Since the 16th century, grassland cultivation has been practiced over the Crau plain (Southern France) with a traditional irrigation technique, which consists in flooding meadows with large amounts of water withdrawn from the Durance River. Originating from the Alps, this water is distributed over the Crau plain through a dense network of irrigation channels. The excess of irrigation water flows towards the water table, providing the main contribution to the recharge of this aquifer. In recent decades, the Crau aquifer became an example of the complexity of the resource management issues that combine environmental and socio-economic considerations. Irrigated meadows contribute to providing the main drinking water resource for over 300,000 inhabitants in the area. This large-scale artificial recharge is essential for local populations, but also for several industrial complexes, for agricultural activities, and for some directly connected protected wetlands. A possible reduction in irrigation fluxes due to the need for water saving or to a future land-use change could substantially reduce the total groundwater recharge, and thus endanger the groundwater resource. A robust quantification of the groundwater budget is thus required to establish sustainable water management in the region.

Implemented in a hydrogeological model, the groundwater mass balance, including recharge, of the Crau aquifer was already proposed by Berard et al. (1995). Another groundwater recharge estimate and its excess irrigation fraction were also calculated through a distributed crop model simulating irrigated meadow production processes over the Crau area (Olioso et al., 2013). The constant and poorly argued infiltration fraction applied on irrigation inflows in the first model, the lack of water budget closure arguments in the second approach, and the absence of sensitivity analysis in both these methods represent the major limitations of these previous estimates.

A preliminary seasonal stable isotope survey over the 20082009 period showed that, at the local scale, groundwater isotopic composition clearly records the mixing between two water masses that contribute to groundwater recharge of the Crau aquifer. Here, our sampling strategy aims at characterizing the entire aquifer, with a multi-annual survey in order to quantify temporal variations in the groundwater composition. Such a stable isotope survey over the entire Crau aquifer has never been performed before. This paper presents an updated piezometric contour map, a new interpretation of the geometry of the aquifer, the spatial distribution of $\delta^{18} \mathrm{O}$ and $\delta^{2} \mathrm{H}$, and proposes to merge these data in a geostatistical approach involving an equivalent homogeneous reservoir. This conceptualization makes it possible to apply a parsimonious isotopic mixing model between two end-members in order to assess the global mass balance and specifically the contributions, and notably their uncertainties, of irrigation return flow and precipitation to the groundwater recharge of the Crau aquifer. This quantification will constitute a straightforward and independent approach to be compared with previous published or unpublished estimates, and will help to constrain a future transient groundwater flow model of this aquifer.

\section{Study site}

\subsection{Hydrogeological setting}

Located near the Rhône delta, in Southern France, the Crau plain ( $540 \mathrm{~km}^{2}$ of surface area) is subject to a Mediterranean climate. It is limited (Fig. 1) to the north by the Alpilles Range, to the east by the Miramas Hills and to the west by the present-day Rhône River delta (an area also known as "Camargue"). The Crau aquifer is a quaternary formation created by the accumulation of rough alluvial deposits carried from the Alps by the Durance River. Different paleo-channels of this river have been identified across the Crau Plain, corresponding to the succession of sea level drops during glacial periods (Colomb and Roux, 1978). Three main sedimentation episodes (dated from $2 \mathrm{Ma}$ to $20 \mathrm{ka}$ ) have formed, after cementation, a heterogeneous layer of puddingstone. At the end of the Würm period (125 to $11 \mathrm{ka}$ ), a tectonic movement led to subsidence of the natural threshold of Orgon (Molliex, 2010; Terrier, 1991) and opened the current passage of the Durance River, towards the North of the Alpilles Range, becoming a tributary of the Rhône River (Cova, 1965; Gouvernet, 1959). Filling the paleo-channels of the Durance River, this puddingstone covers all the Crau Plain and constitutes now the main phreatic aquifer of the region, no longer connected to the Durance River aquifer (Archambault, 1950).

The French Geological Survey (BRGM) published a piezometric contour map of the Crau aquifer (Fig. 1), based on data from October 1967, and including a spatial distribution of transmissivity (Albinet et al., 1969). It is so far the only available piezometric map.

There is no natural river network over the Crau plain and all the surface water transfers occur through an artificial irrigation canal network. The absence of a river network comes from the very flat relief, combined with the high infiltration capacity of natural surfaces, where the puddingstone outcrops with almost no soil layer (Dellery et al., 1964). However, a large proportion of the Crau plain is covered by artificial meadows $\left(140 \mathrm{~km}^{2}\right.$ in 2014$)$ where welldeveloped soils result from a long-term traditional flood irrigation practice.

Starting nearly 500 years ago, the cultivation of grasslands for hay production is still the main agricultural activity of the Crau plain. Irrigation water is supplied from April to October, withdrawn from the Durance River through a dense network of canals. The water also carries a large amount of fine sediments, which have progressively led to the development of a soil layer on irrigated plots (Courault et al., 2010; Dellery et al., 1964). This irrigation method is highly water consuming and produces significant return flows (Courault et al., 2010; Mailhol and Merot, 2007). It is well known that the recharge of the Crau aquifer originates mainly from irrigation excess, but a robust quantification of the water balance remains necessary for the whole Crau aquifer.

\subsection{Existing groundwater mass balance data}

In addition to surface recharge, a lateral groundwater inflow draining two Miocene surrounding Lamanon reliefs has been described (Fig. 1). This zone is located upstream (Northeast) of the Crau aquifer and is clearly identified using a local piezometric map established in January 1950 (Archambault, 1950). This contribution was estimated at $0.74 \mathrm{~m}^{3} \mathrm{~s}^{-1}$ in 1950 .

The main natural discharge occurs along the western margin of the Crau plain (Fig. 1) and supplies a permanent flow of water towards some protected and environmentally sensitive wetlands. Beyond this constant head boundary, groundwater flows into a confined portion of the aquifer, beneath the Rhône delta to the west. Two additional outflows have been identified (Fig. 1): a drai- 


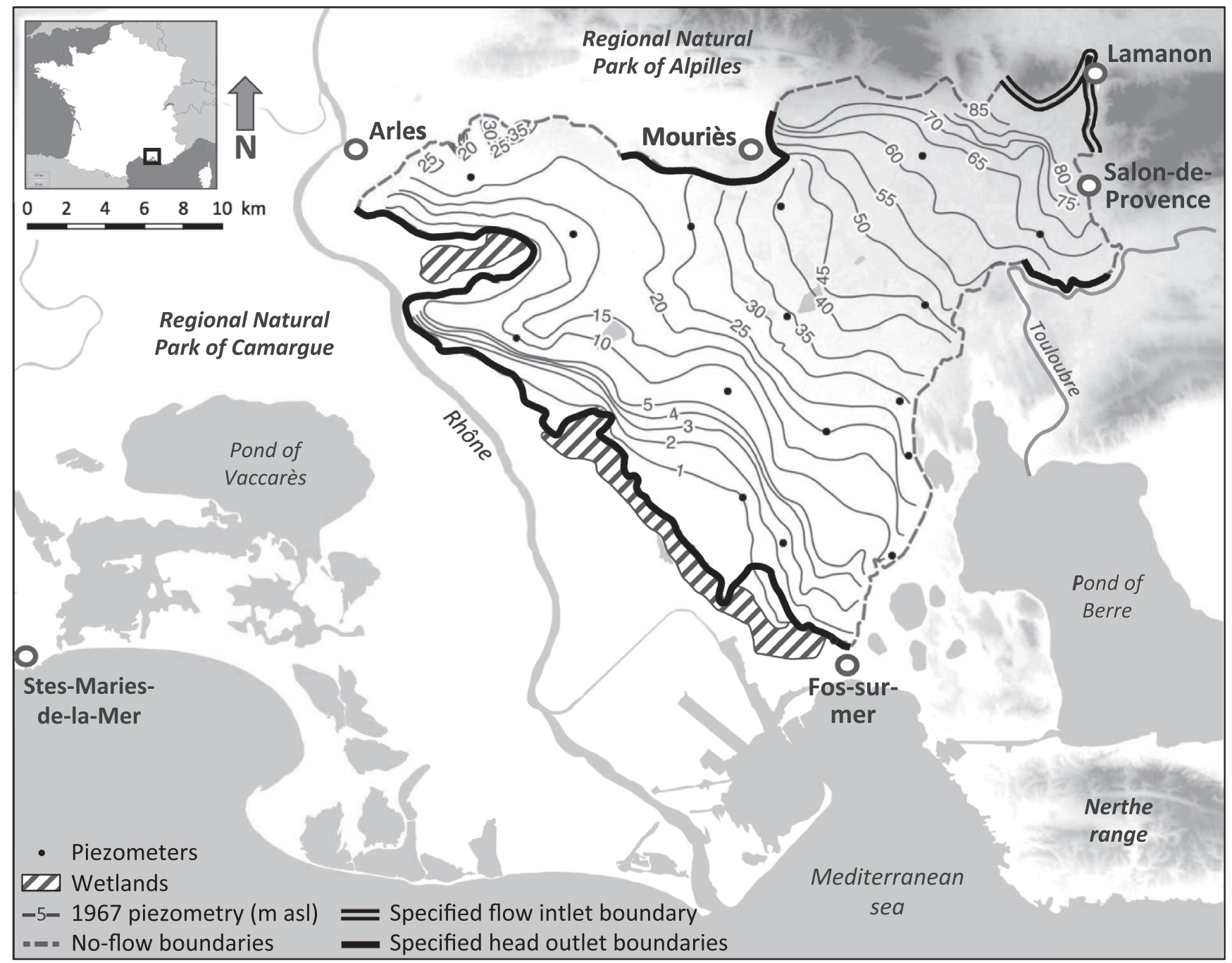

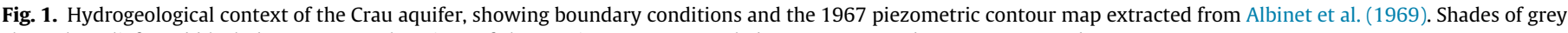
show the reliefs and black dots represent locations of the 17 piezometers sampled every semester between 2011 and 2013.

nage zone towards the Touloubre River east of the Crau plain; and another drainage through a limestone formation located north of the Crau plain. The latter supplies a series of springs with a flow rate estimated by BRGM at about $0.90 \mathrm{~m}^{3} \mathrm{~s}^{-1}$ (Dellery et al., 1964). Recent field measurements that we performed on the main outlet springs ("Mouriès Fountains") showed a flow rate of about $0.20 \mathrm{~m}^{3} \mathrm{~s}^{-1}$. Because this drainage zone is very diffuse and the springs may not be continuously active, the average flux was estimated to be $0.55 \pm 0.35 \mathrm{~m}^{3} \mathrm{~s}^{-1}$.

The Crau aquifer is subject to substantial water abstraction for industrial, agricultural and domestic use. The SYMCRAU (Groundwater Management Union of the Crau plain) recently estimated that industrial uptakes accounted for $0.57 \mathrm{~m}^{3} \mathrm{~s}^{-1}$, domestic water supplies $0.92 \mathrm{~m}^{3} \mathrm{~s}^{-1}$, and agricultural withdrawals about $1.10 \pm 0.41 \mathrm{~m}^{3} \mathrm{~s}^{-1}$. The high uncertainty associated with agricultural uptakes is due to the fact that only a fraction of farmers declared the amount of water withdrawn. This leads to a total groundwater uptake estimated at $2.60 \pm 0.41 \mathrm{~m}^{3} \mathrm{~s}^{-1}$.

The very first groundwater budget of the Crau aquifer calculated by the French Geological Survey using mathematical and analogical models (rheoelectric analogy and resistor-capacitor network) showed a total surface recharge of about $5.50 \mathrm{~m}^{3} \mathrm{~s}^{-1}$ (Albinet et al., 1969). The same study also proposed a first estimate of the groundwater natural recharge assuming zero runoff and applying a simple Thornthwaite water balance method yielding a value of $100 \mathrm{~mm} \mathrm{yr}^{-1}$, i.e. $1.71 \mathrm{~m}^{3} \mathrm{~s}^{-1}$. In 1995, BRGM proposed an updated estimate of groundwater recharges using an infiltration proportion representing a constant fraction of $29 \%$ of the irrigation fluxes supplied to meadows (identified using SPOT images), but without clear argumentation. Using this infiltration ratio, Berard et al. (1995) computed a total recharge by irrigation return flow of $3.71 \mathrm{~m}^{3} \mathrm{~s}^{-1}$ used in their hydrogeological model. In the same study, a value of $1.81 \mathrm{~m}^{3} \mathrm{~s}^{-1}$ was proposed for the recharge by precipitation using a global hydrological model based on precipitation and potential evapotranspiration data. A more recent study was based on the spatialization of the plot-scale crop model "STICS" which uses climate and irrigation practice data to simulate soil infiltration and crop processes (Olioso et al., 2013). For the year 2006, the authors proposed a total surface recharge of $8.78 \mathrm{~m}^{3} \mathrm{~s}^{-1}$, among which $6.88 \mathrm{~m}^{3} \mathrm{~s}^{-1}$ came from irrigation return flows. The other fluxes of the water budget were not quantified in this study.

\section{Isotopic evidence of mixing processes}

\subsection{Data acquisition}

Five groundwater sampling campaigns (October 2011, March 2012, October 2012, March 2013, October 2013) were conducted 
in partnership with the SYMCRAU on 17 piezometers, ensuring a good distribution over the whole aquifer (Fig. 1). For technical reasons, the number of points sampled each time varied between 14 and 17. Additional groundwater samples were collected in spring 2012 (between March and June), for a total of 43 locations, in order to obtain a larger spatial coverage with better resolution. Irrigation water was also collected monthly in the main irrigation channel during the 2014 irrigation season (7 samples).

Samples were analyzed for their isotopic compositions $\left(\delta^{18} \mathrm{O}\right.$ and $\left.\delta^{2} \mathrm{H}\right)$ at CEREGE. Water samples were equilibrated with $\mathrm{CO}_{2}$ ( $10 \mathrm{~h}$ at $291 \mathrm{~K}$ ) and $\mathrm{H}_{2}$ (2 h at $291 \mathrm{~K}$ with a platinum catalyst) for $\delta^{18} \mathrm{O}$ and $\delta^{2} \mathrm{H}$, respectively - in an automated HDO ThermoFinnigan equilibrating unit and measured on a dual inlet Delta Plus mass spectrometer. All the samples were replicated. For technical reasons, some of the samples were analyzed for $\delta^{2} \mathrm{H}$ using a Cavity-Ring-Down laser Spectrometer (WS-CRDS, Picarro L1102-i), also replicated. The total uncertainties for the $\delta^{18} \mathrm{O}$ and $\delta^{2} \mathrm{H}$ values were close to $0.05 \%$ ( $\left.1 \sigma\right)$ and $1 \%$ o $(1 \sigma)$ respectively. Oxygen and hydrogen isotope ratios are reported in \%o relative to the VSMOW-SLAP scale, following the IAEA reference sheet (IAEA, 2009) using three working standards previously normalized using the VSMOW2, SLAP2 and GISP international standards.

\subsection{Mixing process and end-member compositions}

The $\delta^{18} \mathrm{O}-\delta^{2} \mathrm{H}$ plot shows that the groundwater data follow a linear trend $\left(R^{2}=0.96\right.$; Fig. $\left.2 A\right)$. This linear correlation is even better expressed by isolating the 43 data corresponding to spring 2012 $\left(R^{2}=0.99\right.$; Fig. 2C). These groundwater isotopic compositions reflect a mixing between the two main water poles that contribute to groundwater recharge: infiltration of local precipitations ("natural recharge") and irrigation return flows. A thorough characterization of these two end-members is thus necessary in order to apply an isotopic mass balance approach.

The isotopic composition of natural recharge is given by the average composition of groundwater sampled in a perched part of the puddingstone aquifer, located above the regional Crau aquifer water table, where groundwater is not affected by irrigation return flows (Albinet et al., 1969). During the 2008-2009 period, the average groundwater composition was $\delta^{18} \mathrm{O}=-6.00 \pm 0.37 \%$; $\delta^{2} \mathrm{H}=-39.8 \pm 2.0 \%$ o $(\mathrm{n}=15 \quad$ samples $) . \quad$ This groundwater composition is similar to the long-term weighted average of regional precipitations $\left(\delta^{18} \mathrm{O}=-6.21 \pm 2.20 \%\right.$; $\delta^{2} \mathrm{H}=-40.1 \pm 16.8 \%$; at the Avignon GNIP station, $35 \mathrm{~km}$ North of the Crau plain, over the 1997-2009 period; IAEA/WMO, 2016). This similarity indicates that

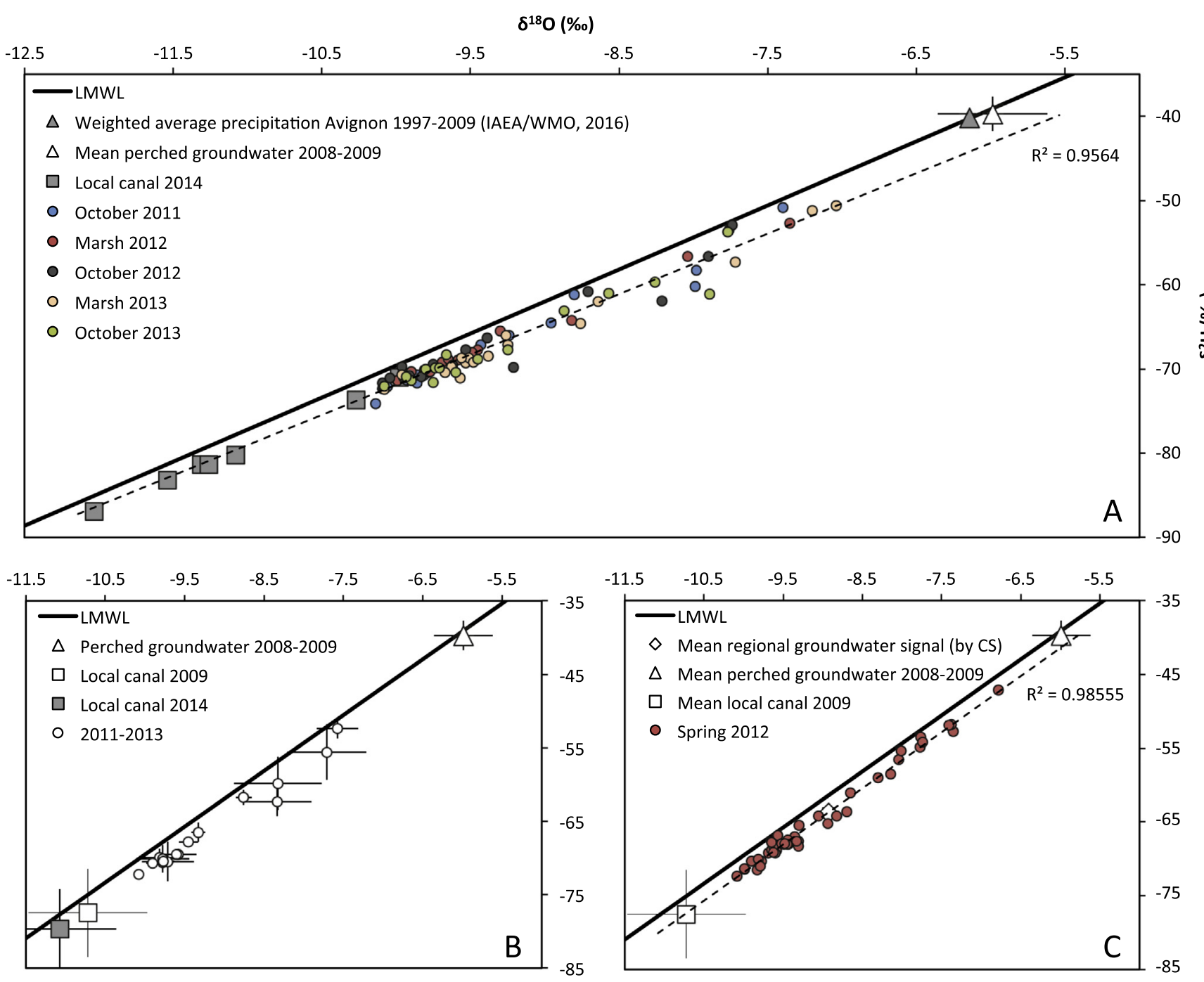

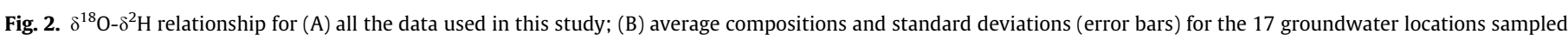

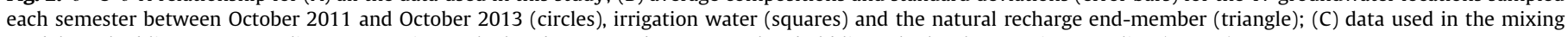
model. Dashed lines represent linear regressions calculated on groundwater samples; bold lines the local meteoric water line (LMWL). 
Table 1

Time variations of the regional isotopic signal of the Crau plain groundwater (13 piezometers sampled).

\begin{tabular}{|c|c|c|c|c|c|c|}
\hline & Oct. 2011 & Mar. 2012 & Oct. 2012 & Mar. 2013 & Oct. 2013 & Long-term average \\
\hline$\delta^{18} \mathrm{O}(\%)$ & -9.32 & -9.27 & -9.35 & -9.10 & -9.31 & -9.27 \\
\hline Mean $( \pm$ SD) & $( \pm 0.91)$ & $( \pm 0.82)$ & $( \pm 0.84)$ & $( \pm 0.92)$ & $( \pm 0.80)$ & $( \pm 0.87)$ \\
\hline$\delta^{2} \mathrm{H}(\%)$ & -67.1 & -66.2 & -66.9 & -65.9 & -67.4 & -66.7 \\
\hline Mean ( \pm SD) & $( \pm 6.7)$ & $( \pm 6.1)$ & $( \pm 6.1)$ & $( \pm 6.9)$ & $( \pm 5.6)$ & $( \pm 6.3)$ \\
\hline
\end{tabular}

the water isotopic composition is not affected by evaporation during the recharge process. The second end-member corresponds to irrigation water. The average composition of water from the main irrigation channel during the 2014 season was $\delta^{18} \mathrm{O}=$ $-10.89 \pm 0.79 \%$; $\delta^{2} \mathrm{H}=-78.2 \pm 6.2 \%$ ( $\left.\mathrm{n}=7\right)$. This depleted isotopic composition, characteristic of alpine rivers (Guglielmi et al., 1998), can be explained by the orographic effect that controls precipitation formation in the Alps. In addition, the 2014 average value is consistent with the weighted average composition of irrigation water sampled during the 2009 irrigation season $\left(\delta^{18} \mathrm{O}=-10.72 \pm 0.75 \%\right.$ o and $\delta^{2} \mathrm{H}=-77.5 \pm 6.0 \%$; $\mathrm{n}=10$ ). The latter was chosen to represent the irrigation end-member (Fig. 2C), since it corresponds to the same time period as the seasonal sampling used to determine the natural end-member composition, and because the 2009 season is characterized by more dense and regular sampling dates.

The slight shift in irrigation water composition below the Local Meteoric Water Line (LMWL; Fig. 2A) probably reflects the influence of evaporation during the transport of water from the Alps. However, irrigation water matches the linear trend of groundwater compositions, indicating that there is no subsequent modification of its isotopic composition during groundwater recharge. In addition, except for some points that fall below the linear trend, the robust alignment of groundwater data between these two end-members confirms that the effect of evaporation does not significantly affect the groundwater isotopic composition during and after infiltration (Fig. 2A). The high infiltration capacity of the puddingstone allows a rapid infiltration and, in most situations, the water table depth prevents evaporation after recharge.

\subsection{Isotopic steady-state assumption}

As the time survey performed on 17 piezometers covered a 25 -month period, both inter-annual and seasonal variations could be observed. The mean regional values presented in Table 1 were calculated using 13 piezometers sampled every semester in order to observe purely temporal variations. It is noteworthy that the average groundwater isotopic composition measured at the end of the three irrigation seasons (October) remained very close to the average value measured in March, when the contribution of natural recharge is expected to be the highest, despite slightly more depleted average values. The time variations of each sampling location were generally small, with the largest variations found for the most enriched isotopic compositions (Fig. 2B). This indicates that the contribution of irrigation return flow seems to have a buffering effect on the long-term groundwater isotopic composition. Individual data (Fig. 2A) show that the most evaporated signatures (i.e. data plotting below the general trend) were found during the October campaigns. These observations, added to the similarity between the spatial average values, computed from the 13 piezometers sampled in March 2012, and the longterm average (Table 1 ), led us to assume that the spring 2012 data set provided the best representation of the steady-state isotopic composition.

\section{Mixing model implementation}

Based on the high isotopic contrast between local precipitations and exogenous irrigation waters (Fig. 2C), the purpose of this study was to use the spatial distribution of these isotopic data to estimate the contributions of irrigation return flow and precipitation infiltration to groundwater recharge at the scale of the whole aquifer. Fig. 3 illustrates two possible approaches to achieve this quantification. The first rigorous one consists in building a fluid-flow and transport hydrogeological model, which can be highly timeconsuming. The heterogeneity of some groundwater reservoirs requires the spatial distribution of parameters such as permeability, specific yield, and dispersivity, which are difficult to estimate. Similarly to Gonçalvès et al., (2015), this study therefore adopted an independent and parsimonious alternative using $\delta^{18} \mathrm{O}$ and $\delta^{2} \mathrm{H}$ as conservative tracers in a simple mass balance mixing model performed at the scale of the entire phreatic aquifer. For this purpose, we consider a fictitious homogeneous reservoir equivalent, from an isotopic standpoint, to the real heterogeneous isotopic reservoir (Fig. 3). Assuming an isotopic steady state, the isotopic composition of the equivalent homogeneous reservoir, combined with the two previously identified end-member compositions, makes it possible to deduce the proportions of irrigation return flow and precipitation infiltration contributing to aquifer recharge. Then, recharge values were estimated using these mixing proportions and the overall groundwater flow values inferred from the average aquifer water balance, obtained by means of simple Darcy flow calculations based on the geometry of the aquifer and on an actualized piezometric map.

\subsection{Conceptualization and mass balance equations}

Assuming a steady state, the main flows previously presented (Section 2.2) can be summarized by a simple groundwater mass balance equation:

$Q_{u}+Q_{\text {out }}=R_{i}+R_{n}+Q_{\text {in }}$

where $Q_{u}$ and $Q_{\text {out }}$ constitute the outlets of the Crau aquifer, with respectively, the total uptake flow rate and the natural outflow $\left(\mathrm{m}^{3} \mathrm{~s}^{-1}\right)$. The inlets, $\mathrm{R}_{\mathrm{i}}$ and $\mathrm{R}_{\mathrm{n}}$, correspond to the unknown surface recharges of the aquifer by irrigation return flow and precipitation (natural recharge) respectively $\left(\mathrm{m}^{3} \mathrm{~s}^{-1}\right)$. And the last inlet, $\mathrm{Q}_{\text {in }}$, is the upstream lateral groundwater inflow $\left(\mathrm{m}^{3} \mathrm{~s}^{-1}\right)$. The hypothesis of an equivalent homogeneous reservoir implies the assumption that all the outflows are characterized by the mean regional isotopic signal of the reservoir considered (Fig. 3). Thus, the groundwater fluxes identified above were used to write the following isotope mass balance equation:

$\delta_{m}\left(Q_{u}+Q_{\text {out }}\right)=\delta_{i} R_{i}+\delta_{n}\left(R_{n}+Q_{\text {in }}\right)$

where $\delta_{\mathrm{m}}, \delta_{\mathrm{i}}$ and $\delta_{\mathrm{n}}$ are the Oxygen 18 or Deuterium isotope ratios (\%o versus VSMOW) of the equivalent homogeneous reservoir, the irrigation water, and the natural recharge, respectively. Combining Eqs. (1) and (2) leads to the following expressions of the two unknown flow rates (irrigation and natural recharge):

$R_{i}=\left(\frac{\delta_{m}-\delta_{n}}{\delta_{i}-\delta_{n}}\right)\left(Q_{\text {out }}+Q_{u}\right)$
$R_{n}=\left(\frac{\delta_{m}-\delta_{i}}{\delta_{n}-\delta_{i}}\right)\left(Q_{\text {out }}+Q_{u}\right)-Q_{\text {in }}$ 


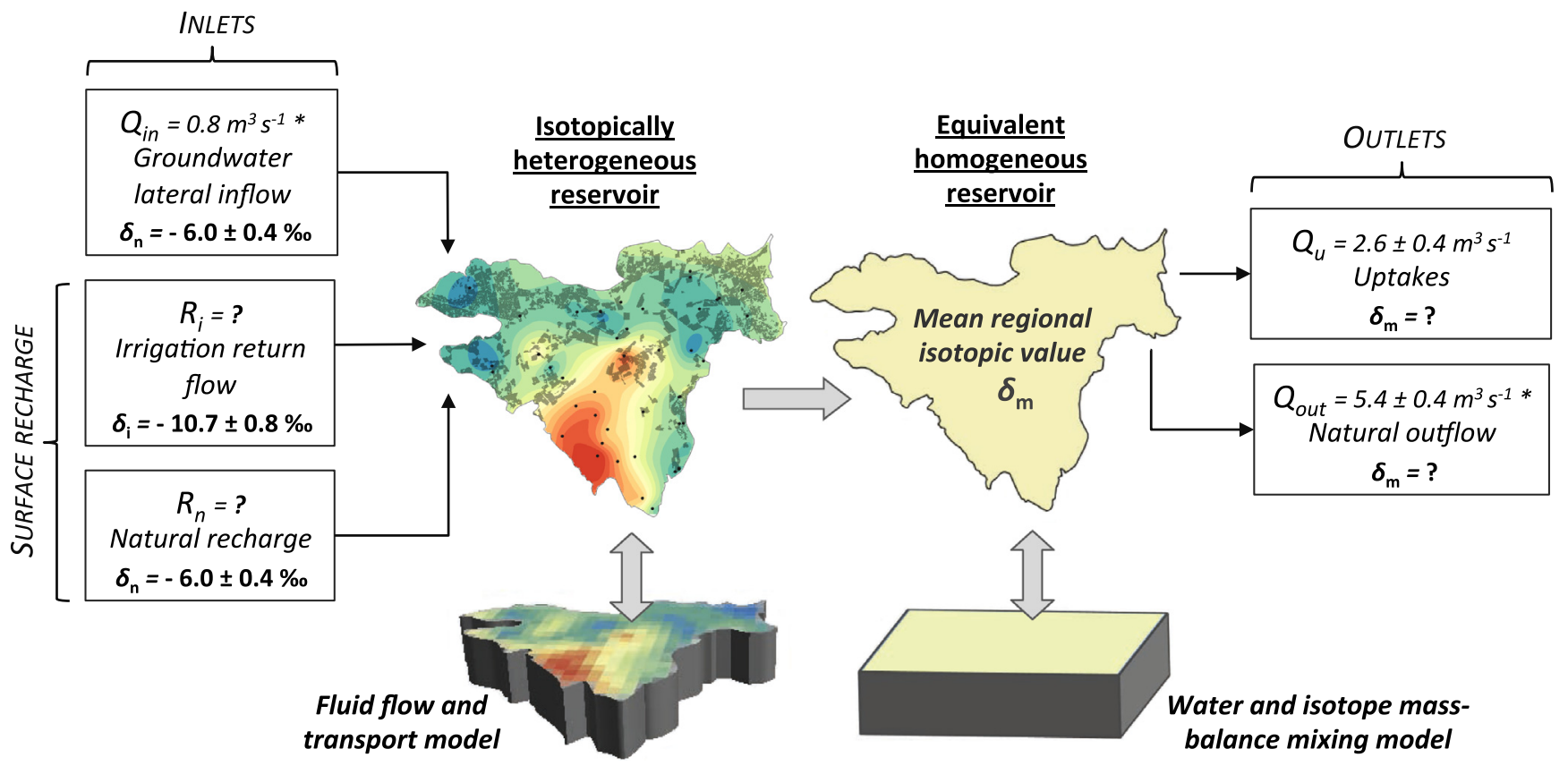

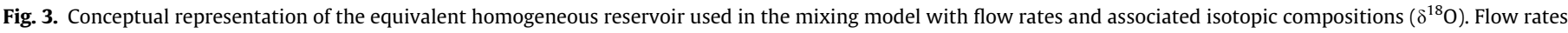
marked by asterisks were estimated by Darcy flow calculations (see Section 4.2.3).

Consequently, the resolution of this simple model requires the identification of a unique mean regional isotopic value $\left(\delta_{\mathrm{m}}\right)$, but also the quantification of the natural outlets $\left(Q_{\text {out }}\right)$ and the upstream lateral groundwater inflow $\left(Q_{\text {in }}\right)$.

\subsection{Geostatistical approaches}

Because of the irregular sampling locations, a simple algebraic mean of the isotopic data would not be representative of the entire reservoir. Similarly to Gonçalvès et al. (2015), the isotopic value of the equivalent homogeneous reservoir $\delta_{\mathrm{m}}$ (characterized hereafter by mean and standard deviation) was estimated by averaging regional values of equiprobable maps, computed by geostatistical conditional simulations (CS) using the spring 2012 isotopic data. This method ought to provide a more reliable representation of the isotopic signal, respecting the spatial correlation inferred from the data. In this approach, the averaging weights are the groundwater volume contained in each geostatistical grid assuming a constant, although poorly known, specific yield value (e.g. 10\%; Dellery et al., 1970). Consequently, the saturated thickness has to be identified to compute the regional isotopic value $\left(\delta_{\mathrm{m}}\right)$ accurately representing the equivalent homogenous reservoir. In addition, the spatial distribution of the saturated thickness is also necessary to obtain updated values of the inflows and outflows by Darcy flow calculations, and thus to solve Eqs. (3) and (4). The saturated thickness is obtained using water table elevation and bedrock geometry (See Sections 4.2.2 and 4.2.1). Bedrock geometry was computed by subtracting the aquifer thickness from the digital elevation model (GO-13, 2009). Therefore, a geostatistical approach was also used to ascertain the aquifer geometry and the piezometric surface. All the interpolations and geostatistical treatments presented below were performed on a regular geostatistical grid $(500 \mathrm{~m} \times 500 \mathrm{~m})$ using the statistical software "R" (Ihaka and Gentleman, 1996).

\subsubsection{Geometry of the reservoir}

Extracted from the BRGM stratigraphic database (BRGM, 2016), 761 geological logs reaching the bedrock of the puddingstone layer were used. In addition, 128 incomplete geological logs (not reach- ing the bedrock) were locally added where the interpolation computed a thickness lower than that given by these additional logs. This constrains the geometry of the paleo-channels, and improves the resolution of the spatialization. The interpolation was also constrained by outcrop locations of stratigraphic layers older than the puddingstone given by the hydrogeological map of the Crau aquifer (Albinet et al., 1969). These data lead to a spherical type model variogram (Fig. 4). Anisotropy (orientation $=20^{\circ} \mathrm{N}$; ratio $=0.33$ ) was added to this model in order to better describe the geometry of the paleo-channels. The interpolation by kriging yields a thickness contour map of the puddingstone layer (Fig. 4) showing an average thickness of $12.6 \mathrm{~m}$.

\subsubsection{Piezometric map}

Here we propose an up to date piezometric map of the Crau aquifer based on our field campaign results. Combined with the geometry of the reservoir and the digital elevation model (GO-13, 2009), it enabled the saturated thicknesses necessary to weight each point of the simulated isotopic maps to be estimated, and a mean regional isotopic value describing the equivalent homogenous reservoir to be computed (see Section 4.2.4). The spatial distribution of saturated thicknesses is also necessary to calculate updated inflows and outflows (see Section 4.2.3). This piezometric map is based on new data acquired during a field campaign conducted in partnership with the SYMCRAU on October 24th and 25th, 2013. Water table depth measurements were combined with ground elevations measured by Differential Global Positioning System to obtain 132 water table elevation data. These data form an unbounded variogram suggesting the existence of a linear geographical trend of the data (Deutsch et al., 1992). Anisotropy was detected on variograms oriented at $45^{\circ} \mathrm{N}$ and $135^{\circ} \mathrm{N}$ consistent with the groundwater flow orientation (NE-SW) of the aquifer. In order to obtain relevant local piezometric level estimators, the linear trend was extracted using ordinary least squares (OLS) method, then residuals were computed. The geostatistical analysis made on the residuals leads to a spherical type variogram model (Fig. 5). In the kriging process, prescribed head boundaries were added to the interpolation data as constraints depending on 


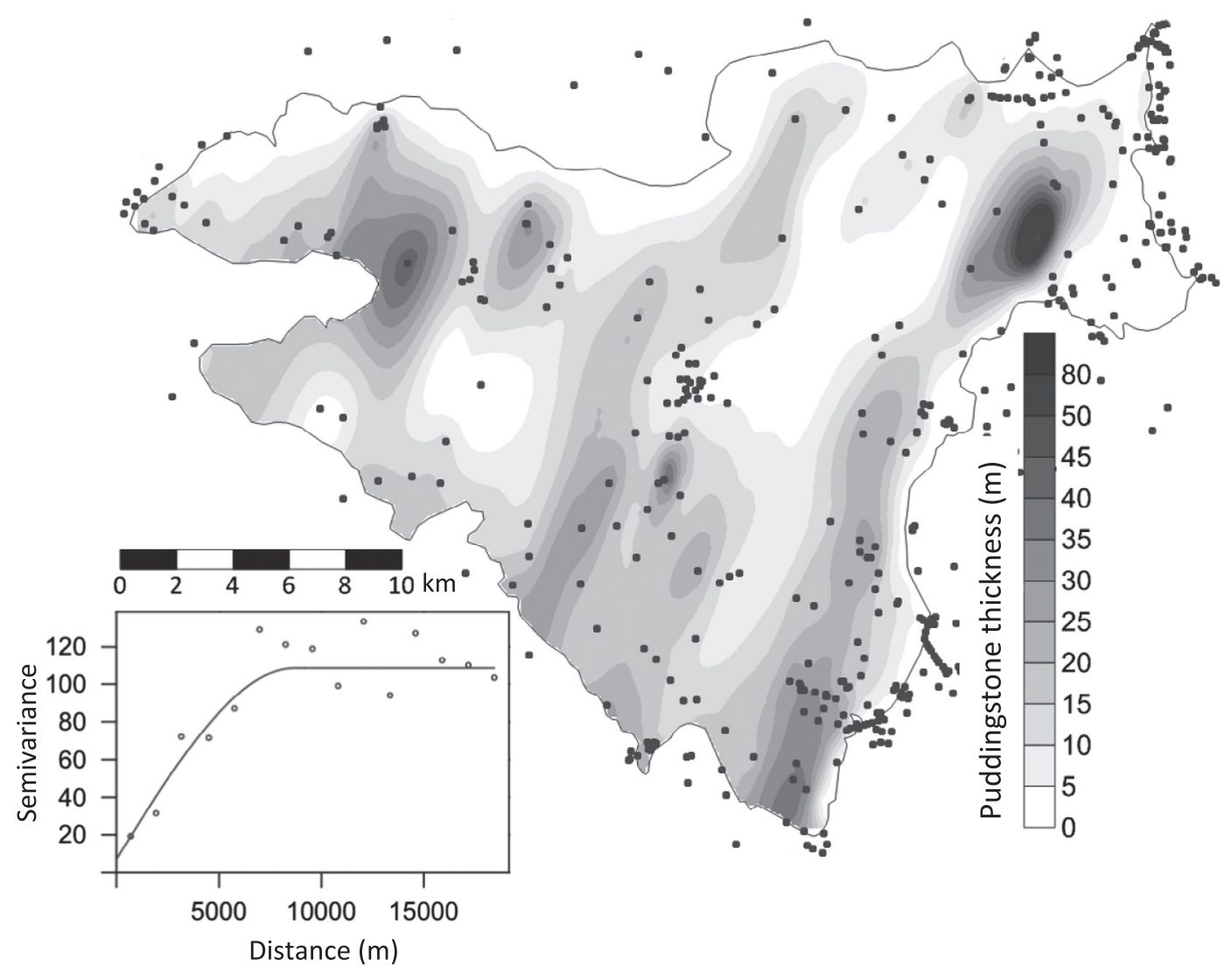

Fig. 4. Contour map of the aquifer thickness and its associated variogram. Black dots represent locations of stratigraphic logs used in the kriging.

the elevation of the outlet wetlands (Meyranne marsh to the northwest) given by the digital elevation model (GO-13, 2009). Water elevations of the springs of Mouriès (to the north), and the Touloubre River (to the east) were also added as constraints. The kriging interpolation yields the piezometric contour map shown in Fig. 5.

\subsubsection{Quantifying $Q_{o u t}$ and $Q_{\text {in }}$ terms of the groundwater budget}

A Darcy flow calculation was performed on each cell of the geostatistical grid identified as an inlet or outlet boundary of the aquifer. In order to calculate these boundary flows, the transmissivity and piezometric contour maps given by the 1967 hydrogeological map (Albinet et al., 1969) were digitized and re-interpolated, yielding a regular grid of transmissivities and water elevation data. However, because transmissivity depends on saturated thickness, the 1967 values were updated (Fig. 5) according to the variation of the piezometric surface.

\subsubsection{Mapping the groundwater isotopic composition}

The regional distribution of groundwater isotopic compositions was calculated through conditional simulations (CS), using the $\mathrm{R}$ package "Gstat" (Pebesma and Wesseling, 1998). Based on the spherical model fitting the experimental variogram used for the kriging of the isotopic data (Fig. 6), these $\mathrm{N}$ simulations provide many equiprobable maps (here $\mathrm{N}=100$ ) of the isotopic spatial distribution. Note that since a regular grid was used and a constant mean specific yield is assumed, the weights of the volume averaging approach are simply the saturated thickness of the aquifer. Hence, an average value for each simulated isotopic map can be computed providing $\mathrm{N}$ equiprobable values of the homogenized regional isotopic composition. Finally, these $\mathrm{N}$ values give the required mean isotopic signal and standard deviation of the equivalent homogeneous reservoir $\delta_{\mathrm{m}}$. A stabilization of the mean and standard deviation of the regional average value was observed after 60 simulations (variations of the mean $\delta^{18} \mathrm{O}$ lower than $0.01 \%$ ) justifying the limitation to 100 simulations.

\section{Results}

Because of the linear correlation between $\delta^{18} \mathrm{O}$ and $\delta^{2} \mathrm{H}$ data (Fig. 2), very similar results are expected using $\delta^{18} \mathrm{O}$ or $\delta^{2} \mathrm{H}$ data. So only the $\delta^{18} \mathrm{O}$ results will be shown, while both results will be discussed. The kriging of the 43 isotopic measurements of groundwater presents a heterogeneous distribution of the $\delta^{18} \mathrm{O}$ values at the aquifer scale (Fig. 6). This map shows a clear consistency between the most depleted isotopic compositions and the distribution of irrigated areas, reflecting the evident influence of irrigation return flow on groundwater recharge. Based on the conditional simulations (CS) performed on the spring 2012 data, the isotopic composition of the equivalent homogeneous reservoir $\left(\delta_{\mathrm{m}}\right)$ was $-8.92 \pm 0.08 \%$ or for $\delta^{18} \mathrm{O}$, and $-63.8 \pm 0.7 \%$ o for $\delta^{2} \mathrm{H}$.

In Fig. 5, the results of the Darcy flow calculations performed on the new piezometric map (except for the $-0.55 \pm 0.35 \mathrm{~m}^{3} \mathrm{~s}^{-1}$ measured flow; see section 2.2) yielded a total natural discharge ( $\mathrm{Q}_{\text {out }}$ ) of about $5.35 \pm 0.35 \mathrm{~m}^{3} \mathrm{~s}^{-1}$. The upstream lateral groundwater inflow $\left(Q_{\text {in }}\right)$ was estimated at $0.83 \mathrm{~m}^{3} \mathrm{~s}^{-1}$ in $2013\left(0.74 \mathrm{~m}^{3} \mathrm{~s}^{-1}\right.$ in 1950; Section 2.2). At this step, there are only two unknown values remaining in the system of two equations, (1) and (2): the recharge by irrigation return flow $R_{i}$, and by precipitation $R_{n}$ (Eqs. (3) and (4)) and their associated standard deviations, expressed by:

$$
\begin{aligned}
\sigma_{R_{i}}^{2}= & \left(\frac{\partial R_{i}}{\partial \delta_{m}}\right)^{2} \sigma_{\delta_{m}}^{2}+\left(\frac{\partial R_{i}}{\partial Q_{u}}\right)^{2} \sigma_{Q_{u}}^{2}+\left(\frac{\partial R_{i}}{\partial Q_{\text {out }}}\right)^{2} \sigma_{Q_{\text {out }}}^{2} \\
& +\left(\frac{\partial R_{i}}{\partial \delta_{n}}\right)^{2} \sigma_{\delta_{n}}^{2}+\left(\frac{\partial R_{i}}{\partial \delta_{i}}\right)^{2} \sigma_{\delta_{i}}^{2}
\end{aligned}
$$




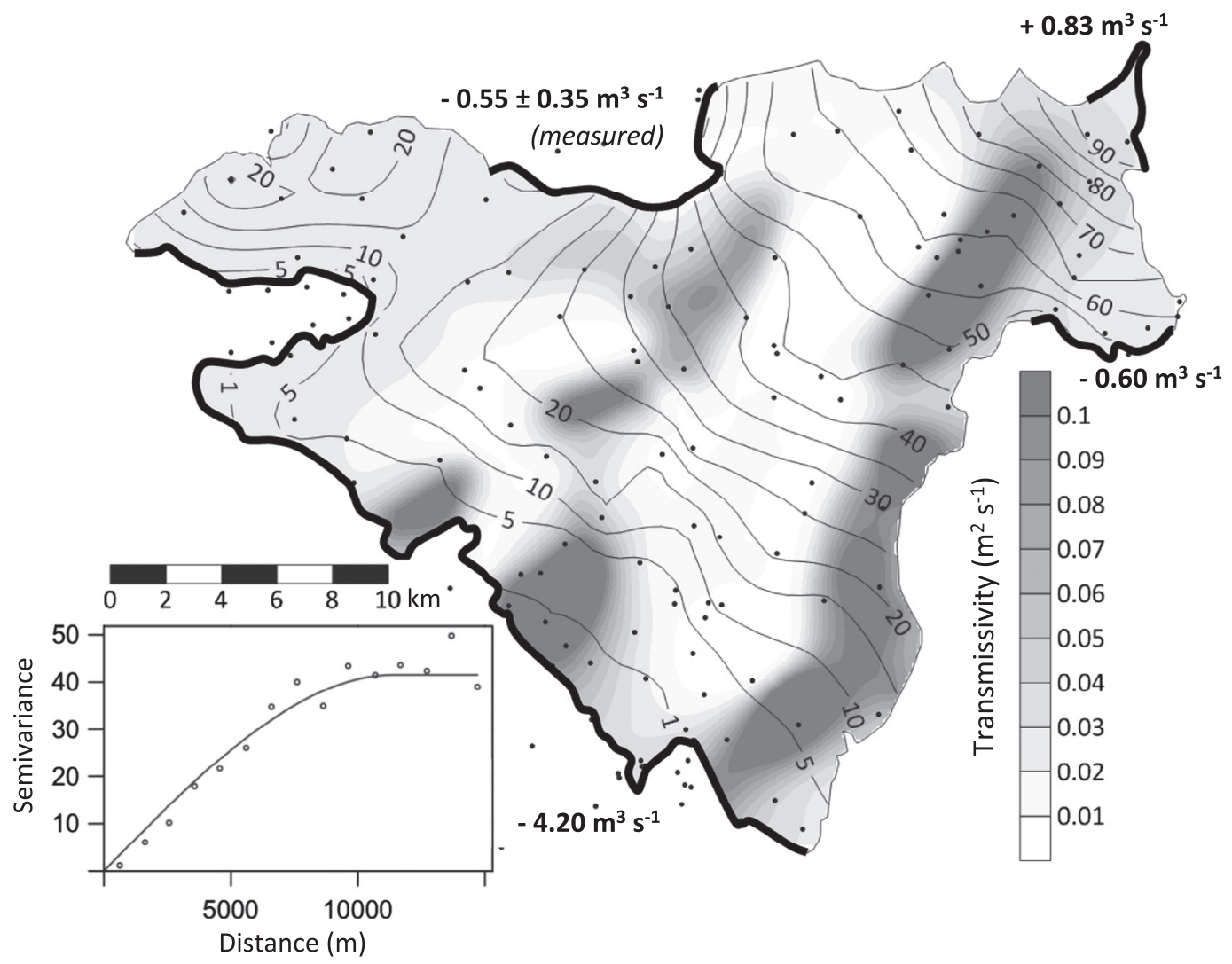

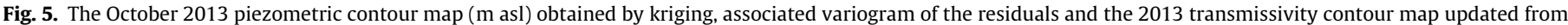
Albinet et al., (1969). Black dots represent locations of water table elevation data, and bold lines, the outlet and inlet boundaries with their associated flow rates.

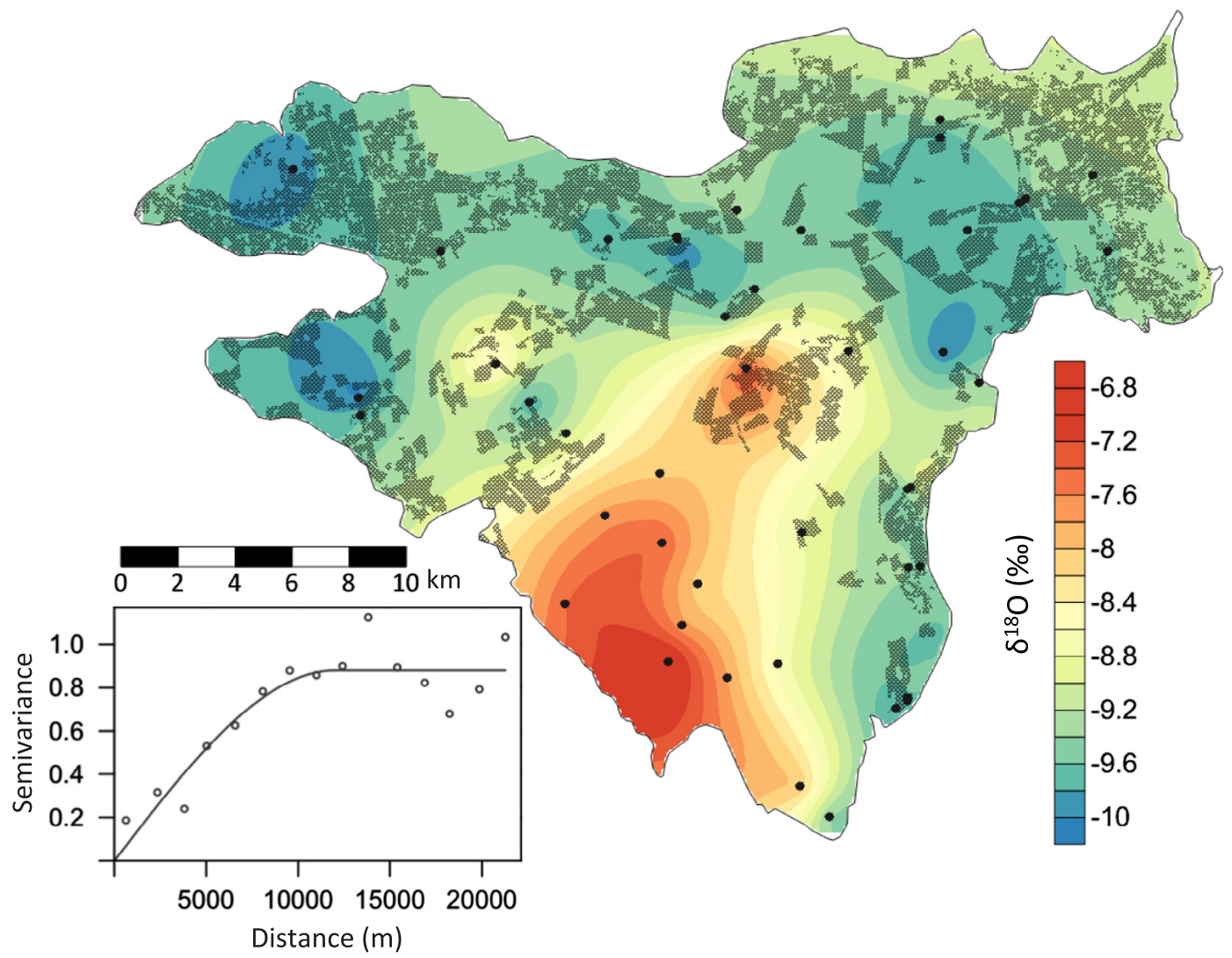

Fig. 6. Contour map of the spring 2012 groundwater $\delta^{18} \mathrm{O}$ composition and its associated variogram used for kriging. Black dots represent locations of the groundwater samples, and grey areas the irrigated meadows. 


$$
\begin{aligned}
\sigma_{R_{n}}^{2}= & \left(\frac{\partial R_{n}}{\partial \delta_{m}}\right)^{2} \sigma_{\delta_{m}}^{2}+\left(\frac{\partial R_{n}}{\partial Q_{u}}\right)^{2} \sigma_{Q_{u}}^{2}+\left(\frac{\partial R_{n}}{\partial Q_{\text {out }}}\right)^{2} \sigma_{Q_{\text {out }}}^{2} \\
& +\left(\frac{\partial R_{n}}{\partial \delta_{n}}\right)^{2} \sigma_{\delta_{n}}^{2}+\left(\frac{\partial R_{n}}{\partial \delta_{i}}\right)^{2} \sigma_{\delta_{i}}^{2}
\end{aligned}
$$

Applying Eqs. (3)-(6) leads to $\mathrm{R}_{\mathrm{i}}=4.92 \pm 0.89 \mathrm{~m}^{3} \mathrm{~s}^{-1}$, i.e. an average value of $1109 \pm 202 \mathrm{~mm} \mathrm{yr}^{-1}$ over $140 \mathrm{~km}^{2}$ of irrigated areas, and $R_{n}=2.19 \pm 0.85 \mathrm{~m}^{3} \mathrm{~s}^{-1}$, i.e. $128 \pm 50 \mathrm{~mm} \mathrm{yr}^{-1}$ over $540 \mathrm{~km}^{2}$ of total aquifer area. Thus, the irrigation return flows contribute about $69 \pm 9 \%$ to the recharge by surface waters, and the remaining $31 \pm 9 \%$ comes from precipitation. Using the 1991-2011 average precipitations (Météo-France, 2016) of the three meteorological stations surrounding the Crau aquifer, i.e. $602 \mathrm{~mm} \mathrm{yr}^{-1}$, it is possible to deduce a mean effective infiltration capacity of $21 \pm 8 \%$ for precipitations. Furthermore, considering a mean irrigation amount of $2250 \pm 250 \mathrm{~mm}$ per season (The local agricultural council), it is also possible to estimate a mean irrigation return flow ratio of $49 \pm 10 \%$.

\section{Discussion}

\subsection{Limitations of the model}

A first limitation of this method is related to the estimation of the groundwater budget flow rates using Darcy's law. These calculations are averages and cannot provide uncertainties because of the absence of uncertainties of the transmissivity map (Albinet et al., 1969). The method may also produce contrasted flow rates depending on the precision of the input data, and especially, the extension of the boundary conditions.

From an isotopic standpoint, the assumption of a constant composition of the two end-members constitutes a limitation of the model. Some seasonal and interannual shifts of the pure isotopic end-members may occur and impact the calculation of the mean regional isotopic value. Thus, the standard deviations of the two isotopic end-members, corresponding to the measured seasonal variability, were included in the calculation of the surface groundwater recharges. Regarding the interannual variability, the similarity of the mean annual signals in 2009 and 2014, and their standard deviations, suggest that the interannual variations of this pole appear to be of the same magnitude as seasonal variations (Fig. 2B) This is consistent with an expected buffering effect of the large Durance River catchment, including the Serre-Ponçon retention dam. Since there are no modifications of the isotopic signal during infiltration of precipitations (see Section 3.2), the variations in the natural recharge end-member can be obtained from the GNIP rainfall record. High monthly variations are classically observed in rainfall composition, but it is interesting to assess temporal variations in the end-member composition with respect to the average residence time of the aquifer. Considering an average aquifer thickness of $12.6 \mathrm{~m}$ (see Section 4.2.1), a specific yield of $10 \%$ (Dellery et al., 1970), and a total recharge of $7.94 \pm 0.87 \mathrm{~m}^{3} \mathrm{~s}^{-1}$, the mean residence time is $2.7 \pm 0.2$ years. Hence, interannual variations of the natural recharge pole are observed by computing the mobile weighted average rainfall isotopic signal over 3 years (between September and August over the 1997-2009 period; IAEA/WMO, 2016). It leads to 10 mean tri-annual isotopic compositions varying from $-5.66 \%$ to $-6.81 \%$ for $\delta^{18} \mathrm{O}(\mathrm{SD}=0.41 \%$ ), and from -36.6 to $-45.5 \%$ o for $\delta^{2} \mathrm{H}(\mathrm{SD}=2.7 \%$ ). These interannual fluctuations are of the same magnitude as seasonal variations of the natural recharge end-member $\quad\left(\delta^{18} \mathrm{O}=-6.00 \pm 0.37 \% ; \quad \delta^{2} \mathrm{H}=-39.8 \pm 2.0 \%\right.$; See Section 3.2). Thus, reasonable stability is expected for both end-member compositions, regarding the average groundwater residence time and we assume that the values used in the mixing model constitute a good representation of steady-state conditions.

Another limitation of the method might be attributed to the representativity of groundwater isotopic data sampled at a given time (Spring 2012) used to calculate steady-state flows. As discussed in Section 3.3, the data set used in this study is representative of the steady-state. Nevertheless, it is crucial to analyze, at the aquifer scale, the possible impact of annual and interannual variability of the groundwater isotopic signal on the results. As previously demonstrated with the calculation of the residence time (i.e. 2.7 years), groundwater has an isotopic signature affected by, at least, an entire season of recharge events (irrigation and/or precipitation). This temporal integration capacity of stable groundwater isotopes is illustrated by the 5 bi-annual campaigns (Table 1 ): after six months of irrigation (October), or six months with no irrigation (Marsh), very low fluctuations of the mean groundwater signal were observed. So, time variations of the regional signal of the equivalent homogeneous reservoir are very low, and their impact on the mixing model results is masked by the time variations of the end-members. This shows that the use of stable isotopes of water on alluvial aquifers allows the groundwater samples to integrate time variations (at a time scale depending on the residence time). Thus, combined with geostatistical conditional simulations, this geochemical tracer is a powerful tool to assess a near steady-state regional signal that is representative of an equivalent homogeneous reservoir.

\subsection{Comparison with the 1967 situation}

The evolution of the hydrodynamic functioning of the Crau aquifer since 1967 can be observed from the previous piezometric map and historical data. First, the comparison between the October 1967 (Fig. 1) and October 2013 (Fig. 5) piezometric contour maps reveals significant differences ( $>10 \mathrm{~m}$ ) mainly located on the north and northeast boundaries. This is due to the fact that specified heads of the outlet springs were added to the 2013 interpolation data while BRGM did not use these constraints to establish the 1967 piezometric map. Note that this earlier piezometric contour map was presumably obtained by conventional interpolation approaches and not by more robust geostatistical methods. Local changes in the water levels (up to $5 \mathrm{~m}$ ) are also observed on the rest of the map for a mean drop of about $0.06 \mathrm{~m}$ between 1967 and 2013. However, by excluding the northeast piezometric data not constrained by BRGM, the regional piezometric drop may be more significant (around $0.45 \mathrm{~m}$ ). According to Dellery et al. (1964), the total surface of meadows was higher than at present $\left(170 \mathrm{~km}^{2}\right)$ while the total uptake flow rates were much lower $\left(0.95 \mathrm{~m}^{3} \mathrm{~s}^{-1}\right)$. The piezometry is thus consistent with the reduction in artificial recharge and the increase in uptakes observed in the last 50 years. However, this is valid only under the assumption of similar irrigation periods in 1967 and 2013. Indeed, considering the significant and rapid seasonal water table fluctuations (a seasonal magnitude up to $8 \mathrm{~m}$ was observed for the most irrigation-influenced piezometers), slight shifts in timing between piezometric campaigns and/or irrigation periods can impact and distort such comparisons. But, thanks to the anthropogenic control created by this irrigation practice, the regional piezometric variations observed here $(0.06-0.45 \mathrm{~m})$ remain low with respect to the significant increase in water use in the last half century. Irrigation return flows thus seem to have a buffering effect on average groundwater storage at the inter-annual time scale.

\subsection{Comparison with previous estimates}

Table 2 summarizes the groundwater budgets proposed in the literature for the Crau aquifer. The flow rate of natural recharge 
Table 2

Summary of groundwater budgets of the Crau aquifer deduced from previous studies. The flows in parentheses correspond to an assumption made by the authors.

\begin{tabular}{|c|c|c|c|c|c|}
\hline & & Albinet et al. (1969) & Berard et al. (1995) & Olioso et al. (2013) & This study \\
\hline \multirow[t]{2}{*}{ Outlets } & Uptakes $\left(\mathrm{m}^{3} \mathrm{~s}^{-1}\right)$ & $(0.5)$ & 1.90 & l & $2.60 \pm 0.41$ \\
\hline & Natural discharge $\left(\mathrm{m}^{3} \mathrm{~s}^{-1}\right)$ & $5.75 \pm 0.43$ & 4.41 & l & $5.34 \pm 0.35$ \\
\hline \multirow[t]{5}{*}{ Inlets } & Lateral upstream inflow $\left(\mathrm{m}^{3} \mathrm{~s}^{-1}\right)$ & 1.00 & 0.79 & l & 0.83 \\
\hline & Recharge by irrigations $\left(\mathrm{m}^{3} \mathrm{~s}^{-1}\right)$ & 3.79 & 3.71 & 6.88 & $4.92 \pm 0.89$ \\
\hline & Proportion of artificial recharge & $69 \%$ & $67 \%$ & $78 \%$ & $69 \pm 9 \%$ \\
\hline & Natural recharge $\left(\mathrm{m}^{3} \mathrm{~s}^{-1}\right)$ & 1.71 & 1.81 & 1.90 & $2.19 \pm 0.85$ \\
\hline & Proportion of natural recharge & $31 \%$ & $33 \%$ & $22 \%$ & $31 \pm 9 \%$ \\
\hline
\end{tabular}

computed in this study appears to be consistent, although slightly higher than the previously estimated values. Solving a groundwater mass balance equation implies that the recharge estimate depends on the quantification of the discharge. As previously mentioned, the choice of the aquifer limits can be a major source of error, especially for the main natural discharge on the southwest border presenting very low hydraulic gradients. Different estimates of the total uptakes and the upstream groundwater drainage could also partly explain these differences. But, despite a slight discrepancy regarding the absolute flux values, similar orders of magnitudes are obtained between these different studies for the respective proportions of natural recharge and irrigation return flow. Nevertheless, stable isotopes of water constitute a robust and independent geochemical tracer for partitioning groundwater recharges at the scale of the entire aquifer. In addition, the method proposed in this study also has the advantage of providing uncertainties characterizing, inter alia, time variations in the estimated flows.

\section{Conclusion}

The new piezometric map and the aquifer geometry produced in this study were used to infer the groundwater budget of the Crau aquifer (southern France). Stable isotopes of water data, implemented in an equivalent one-reservoir mixing model, successfully yielded the contributions of different surface groundwater recharges that are difficult to dissociate with conventional methods. Nearly at steady-state, the spring 2012 set of isotopic data treated by conditional simulations leads to a recharge by irrigation of $4.92 \pm 0.89 \mathrm{~m}^{3} \mathrm{~s}^{-1}$, i.e. $1109 \pm 202 \mathrm{~mm} \mathrm{yr}^{-1}$ (with respect to the current irrigated surfaces), and a natural recharge of $2.19 \pm 0.86 \mathrm{~m}^{3} \mathrm{~s}^{-1}$, i.e. $128 \pm 50 \mathrm{~mm} \mathrm{yr}^{-1}$. Thus, about two thirds of the groundwater recharge are derived from a specific agricultural practice dating back nearly five centuries, confirming the dominant influence of anthropogenic control on this aquifer. Moreover, this study shows that geostatistical conditional simulation is a powerful tool to assess a relevant mean regional variable, and applied to stable isotope data, it provides an average groundwater isotopic composition representative of the steady-state situation. Finally, the conceptualization of an equivalent homogeneous reservoir provides an independent and straightforward approach to constrain the groundwater recharge values for a future transient model of groundwater flow and transport.

\section{Acknowledgements}

This study is part of a Ph.D. funded by the SYMCRAU and the PACA region. It has been supported by CNRS-INSU, through the SICMED-CRAU research project. We gratefully thank the SYMCRAU team for their collaboration and their valuable contribution to the field campaigns, Philippe Dussouillez for his contribution to the piezometer leveling campaign, and Fernando A.L. Pacheco and the two others anonymous reviewers for their relevant comments and suggestions.
Appendix A. Results of stable isotopes measurements used in this study

A.1. Results of 43 stable isotope measurements of the Crau plain groundwater in spring 2012

\begin{tabular}{|c|c|c|c|c|c|}
\hline ID & X (WGS84 & Y (WGS84) & $\begin{array}{l}\text { Sampling } \\
\text { date }\end{array}$ & $\begin{array}{l}\delta^{18} \mathrm{O} \\
(\% o)\end{array}$ & $\begin{array}{l}\delta^{2} \mathrm{H} \\
(\% o)\end{array}$ \\
\hline Q1 & 4.84095 & 43.63939 & $3 / 28 / 2012$ & -9.69 & -69.2 \\
\hline Q2 & 4.76807 & 43.63736 & $3 / 26 / 2012$ & -9.58 & -68.9 \\
\hline Q3 (P13) & 4.70528 & 43.66455 & $3 / 26 / 2012$ & -9.90 & -70.3 \\
\hline Q4 & 4.98666 & 43.66812 & $3 / 27 / 2012$ & -9.77 & -70.3 \\
\hline Q5 & 4.89923 & 43.59736 & $3 / 27 / 2012$ & -7.35 & -52.7 \\
\hline Q6 & 4.86042 & 43.56497 & $3 / 29 / 2012$ & -8.04 & -56.6 \\
\hline Q7 (PZ16) & 5.05754 & 43.63046 & $3 / 27 / 2012$ & -9.45 & -67.7 \\
\hline Q8 & 4.89749 & 43.64721 & $3 / 26 / 2012$ & -9.30 & -65.5 \\
\hline Q9 & 4.98500 & 43.60029 & $3 / 27 / 2012$ & -9.99 & -71.4 \\
\hline Q10 & 4.96728 & 5732 & $3 / 28$ & -9.65 & -68.8 \\
\hline Q11 & 4.92098 & 4501 & $3 / 26$ & -8.82 & -64.2 \\
\hline Q12 & 4.97148 & 43.5 & $3 / 28 / 2$ & -9.49 & -68.0 \\
\hline Q13 & 4.86780 & 1678 & $3 / 2$ & -7.76 & -53.5 \\
\hline Q14 & 4.95923 & 43.48835 & $3 / 2$ & -9.81 & -70.1 \\
\hline Q17 & 4.73066 & 9178 & $3 / 2$ & -10.08 & -72.4 \\
\hline PZ1 & 5.05 & 43.6 & $3 / 1$ & -9.30 & -67.6 \\
\hline PZ2 & 5.01988 & 43.6 & $6 / 27 /$ & -9.83 & -71.5 \\
\hline PZ3 & 4.99705 & 43.63864 & $6 / 27 / 2012$ & -9.60 & -69.2 \\
\hline QUANT4 & 4.92471 & 43.64037 & $6 / 27$ & -9.62 & -68.3 \\
\hline PZ5 & 4.87 & 43. & $6 / 2$ & -9.99 & -71.3 \\
\hline QUANT7 & 4.96 & 43. & $3 / 1$ & -8.93 & -65.2 \\
\hline PZ8 & 4.96660 & 43.53273 & $6 / 7 /$ & -9.35 & -67.0 \\
\hline PZ9 & 4.96426 & 43.49161 & $3 / 15 / 2$ & -9.57 & -66.8 \\
\hline PZ10 & 4.92877 & & & -9.43 & -68.0 \\
\hline PZ11 & 4.90852 & 369 & $6 / 7 \mid$ & -8.65 & -61.1 \\
\hline PZ13 & 4.82014 & 43.57860 & $6 / 7 /$ & -9.05 & -64.2 \\
\hline PZ17 & 4.73135 & 43.58633 & $6 / 7 / 2$ & -9.62 & -69.1 \\
\hline P2 & 4.96 & 43.4 & $3 / 15$ & -9.65 & -67.8 \\
\hline P72 & 4.88675 & 43.4 & $3 / 1$ & -7.77 & -54.9 \\
\hline P7 & 4.79044 & 43.60127 & $3 / 16$ & -8.30 & -59.0 \\
\hline P1 Eyguieres & 5.02263 & & & -9.45 & -68.0 \\
\hline P2171 & 4.81742 & 43.52473 & $3 / 16 / 2012$ & -7.37 & -51.8 \\
\hline P26ter & 4.83574 & 43.55210 & $3 / 16 / 2012$ & -7.74 & -54.2 \\
\hline P4 & 4.98691 & 43.67370 & $3 / 16 / 2012$ & -9.31 & -68.3 \\
\hline P5 & 4.99971 & 031 & $3 / 16$ & -9.33 & -67.6 \\
\hline P20 & 4.80476 & 43.58886 & $3 / 16 / 2012$ & -9.79 & -71.0 \\
\hline P33bis & 4.87511 & 43.52956 & $3 / 16 / 2012$ & -8.15 & -58.5 \\
\hline P2 Suffren & 4.94353 & 43.60157 & $3 / 16 / 2012$ & -8.70 & -63.6 \\
\hline P27 Nouveau & 4.86015 & 43.54307 & $3 / 16 / 2012$ & -7.41 & -51.9 \\
\hline P9 & 4.86127 & 43.50553 & $3 / 16 / 2012$ & -6.78 & -47.2 \\
\hline $\mathrm{F}$ & 4.89072 & 43.61391 & $5 / 14 / 2012$ & -9.52 & -67.9 \\
\hline $\mathrm{H}$ & 4.90394 & 43.62216 & $5 / 14 / 2012$ & -9.48 & -67.9 \\
\hline $\mathrm{J}$ & 4.91671 & 43.46473 & $3 / 15 / 2012$ & -8.01 & -55.4 \\
\hline
\end{tabular}


A.2. Results of biannual stable isotope measurements of the Crau plain groundwater in 17 piezometers between 2011 and 2013

\begin{tabular}{|c|c|c|c|c|c|c|c|c|c|c|c|c|}
\hline \multirow[t]{2}{*}{ ID } & \multirow[t]{2}{*}{ X (WGS84) } & \multirow[t]{2}{*}{ Y (WGS84) } & \multicolumn{2}{|l|}{ Oct. 2011} & \multicolumn{2}{|l|}{ Mar. 2012} & \multicolumn{2}{|l|}{ Oct. 2012} & \multicolumn{2}{|l|}{ Mar. 2013} & \multicolumn{2}{|l|}{ Oct. 2013} \\
\hline & & & $\delta^{18} \mathrm{O}(\%)$ & $\delta^{2} \mathrm{H}(\% o)$ & $\delta^{18} \mathrm{O}(\%)$ & $\delta^{2} \mathrm{H}(\%)$ & $\delta^{18} \mathrm{O}(\%)$ & $\delta^{2} \mathrm{H}(\% 0)$ & $\delta^{18} \mathrm{O}(\%)$ & $\delta^{2} \mathrm{H}(\%)$ & $\delta^{18} \mathrm{O}(\%)$ & $\delta^{2} \mathrm{H}(\% 0)$ \\
\hline Q1 & 4.84095 & 43.63939 & -9.81 & -70.7 & -9.69 & -69.2 & -9.96 & -69.7 & -9.63 & -69.7 & -9.90 & -71.4 \\
\hline Q2 & 4.76807 & 43.63736 & -10.14 & -74.1 & -9.58 & -68.9 & -9.83 & -70.9 & -9.25 & -67.1 & -9.75 & -71.6 \\
\hline Q3 (P13) & 4.70528 & 43.66455 & -9.90 & -70.4 & -9.90 & -70.3 & -10.09 & -71.7 & -9.53 & -69.3 & -9.66 & -68.3 \\
\hline Q4 & 4.98666 & 43.66812 & -9.86 & -71.7 & -9.77 & -70.3 & -9.75 & -69.4 & -9.57 & -71.1 & -9.93 & -70.9 \\
\hline Q5 & 4.89923 & 43.59736 & -7.98 & -58.3 & -7.35 & -52.7 & -7.90 & -56.6 & -7.04 & -50.6 & -8.26 & -59.7 \\
\hline Q6 & 4.86042 & 43.56497 & -8.96 & -64.5 & -8.04 & -56.6 & 1 & I & -7.72 & -57.3 & -8.57 & -61.0 \\
\hline Q7 (PZ16) & 5.05754 & 43.63046 & -9.93 & -71.3 & -9.45 & -67.7 & -10.04 & -71.1 & -9.38 & -68.5 & -10.08 & -72.0 \\
\hline Q8 & 4.89749 & 43.64721 & -9.24 & -66.0 & -9.30 & -65.5 & -9.39 & -66.3 & -9.26 & -66.0 & -9.45 & -68.8 \\
\hline Q9 & 4.98500 & 43.60029 & -9.86 & -70.7 & -9.99 & -71.4 & -9.91 & -70.8 & -9.96 & -70.7 & -9.80 & -70.0 \\
\hline Q10 & 4.96728 & 43.55732 & -9.78 & -70.4 & -9.65 & -68.8 & -9.21 & -69.8 & -9.51 & -68.7 & -9.74 & -69.9 \\
\hline Q11 & 4.92098 & 43.54501 & -7.99 & -60.2 & -8.82 & -64.2 & -8.21 & -61.9 & -8.76 & -64.6 & -7.89 & -61.1 \\
\hline Q12 & 4.97148 & 43.53300 & -9.43 & -67.1 & -9.49 & -68.0 & -9.53 & -67.7 & -9.56 & -68.7 & -9.25 & -67.7 \\
\hline Q13 & 4.86780 & 43.51678 & -7.40 & -50.8 & -7.76 & -53.5 & -7.74 & -52.9 & -7.20 & -51.2 & -7.77 & -53.7 \\
\hline Q14 & 4.95923 & 43.48835 & -9.80 & -70.3 & -9.81 & -70.1 & -9.95 & -71.1 & -9.67 & -70.4 & -9.60 & -70.4 \\
\hline Q15 & 4.89193 & 43.49542 & -8.80 & -61.2 & 1 & 1 & -8.71 & -60.8 & -8.64 & -62.0 & -8.87 & -63.1 \\
\hline Q16 & 4.92130 & 43.45104 & 1 & I & I & 1 & -9.62 & -69.5 & -9.48 & -69.2 & -9.71 & -69.9 \\
\hline Q17 & 4.73066 & 43.59178 & -10.06 & -72.1 & -10.08 & -72.4 & -10.09 & -72.3 & 1 & 1 & 1 & 1 \\
\hline
\end{tabular}

Appendix B. Results of 132 water table elevations of the Crau aquifer measured on October 24th and 25th, 2013 (Produced by SYMCRAU)

\begin{tabular}{|c|c|c|c|}
\hline ID & X (WGS84) & Y (WGS84) & $\mathrm{H}(\mathrm{m}$ asl $)$ \\
\hline F5 & 4.92859 & 43.48899 & 5.57 \\
\hline $\mathrm{J}$ & 4.91671 & 43.46473 & 2.41 \\
\hline$\times 11$ & 4.90139 & 43.45849 & 1.52 \\
\hline$\times 25$ & 4.91992 & 43.45098 & 1.16 \\
\hline 8 & 4.87670 & 43.62574 & 35.28 \\
\hline 9 & 4.85992 & 43.62933 & 30.65 \\
\hline 20 & 4.85707 & 43.52077 & 1.54 \\
\hline 41 & 4.74152 & 43.66361 & 19.65 \\
\hline 44 & 4.74614 & 43.68524 & 24.04 \\
\hline 55 & 4.71209 & 43.64547 & 7.40 \\
\hline 75 & 4.79672 & 43.66211 & 11.43 \\
\hline 91 & 4.80575 & 43.63841 & 15.87 \\
\hline 93 & 4.68333 & 43.67111 & 26.12 \\
\hline $92 b$ & 4.74572 & 43.63737 & 5.29 \\
\hline N13 & 4.82820 & 43.62344 & 24.92 \\
\hline N1b & 4.75918 & 43.65109 & 14.41 \\
\hline P42 & 4.86048 & 43.61176 & 28.64 \\
\hline 11 & 4.78495 & 43.60739 & 20.10 \\
\hline 53 & 4.70862 & 43.59302 & 7.20 \\
\hline $39 b$ & 4.74580 & 43.61964 & 14.03 \\
\hline P20 G2C & 4.80476 & 43.58886 & 18.72 \\
\hline P26 & 4.84407 & 43.55806 & 14.73 \\
\hline P7 G2C & 4.84170 & 43.56985 & 16.03 \\
\hline R408 & 4.73418 & 43.57181 & 3.17 \\
\hline 4 & 4.88475 & 43.55441 & 10.90 \\
\hline 10 & 4.88263 & 43.60545 & 32.73 \\
\hline 31 & 4.93802 & 43.56722 & 27.30 \\
\hline 62 & 5.00078 & 43.60864 & 50.10 \\
\hline 67 & 4.91129 & 43.62117 & 39.73 \\
\hline Co72 & 4.99271 & 43.62672 & 54.35 \\
\hline N11 & 4.93438 & 43.55717 & 25.12 \\
\hline N12 & 4.94180 & 43.52887 & 13.99 \\
\hline
\end{tabular}

Appendix B (continued)

\begin{tabular}{|c|c|c|c|}
\hline ID & $\mathrm{X}$ (WGS84) & Y (WGS84) & $\mathrm{H}(\mathrm{m}$ asl $)$ \\
\hline N19 & 4.92117 & 43.54466 & 20.97 \\
\hline P19b & 4.92284 & 43.61216 & 44.40 \\
\hline P21 Entressen & 4.92248 & 43.59524 & 39.00 \\
\hline $\mathrm{P} 23 \mathrm{~T}$ & 4.88545 & 43.57960 & 27.33 \\
\hline P5 & 4.99971 & 43.59031 & 43.90 \\
\hline P7 DIREN & 5.01594 & 43.62909 & 57.21 \\
\hline P8 & 4.95191 & 43.59366 & 44.32 \\
\hline 09933X0088/F & 4.93487 & 43.68011 & 59.67 \\
\hline 09934X0087/P18B & 4.96330 & 43.65283 & 54.61 \\
\hline 09937X0133/P42B & 4.86233 & 43.60819 & 28.49 \\
\hline 09937X0134/P19T & 4.92411 & 43.60916 & 44.53 \\
\hline 09937X0135/P23B & 4.87191 & 43.57802 & 15.24 \\
\hline 10192X0094/F & 4.85830 & 43.47705 & 1.06 \\
\hline 10193X0151/P29B & 4.89616 & 43.55071 & 16.11 \\
\hline 10195X0041/PZ & 4.75684 & 43.44065 & -1.40 \\
\hline 1J N merle & 5.00788 & 43.64418 & 59.60 \\
\hline 1J S merle & 5.00680 & 43.64041 & 58.95 \\
\hline $6 \mathrm{~N}$ merle & 4.98891 & 43.64215 & 60.13 \\
\hline Coussoul merle & 5.00056 & 43.65256 & 60.96 \\
\hline De causans & 4.70736 & 43.61350 & 2.46 \\
\hline Delalix & 4.70542 & 43.66446 & 20.83 \\
\hline Etang des aulnes & 4.79160 & 43.60111 & 17.20 \\
\hline P2 Suffren & 4.94353 & 43.60157 & 44.40 \\
\hline Pz1 & 5.05259 & 43.65460 & 70.21 \\
\hline Pz10 & 4.92877 & 43.45508 & 1.66 \\
\hline Pz11 & 4.90853 & 43.50369 & 6.04 \\
\hline Pz13 & 4.82014 & 43.57860 & 12.85 \\
\hline Pz14 & 4.83982 & 43.63859 & 25.22 \\
\hline Pz15 & 4.78753 & 43.63582 & 15.15 \\
\hline Pz16 & 5.05783 & 43.63050 & 66.37 \\
\hline Pz17 & 4.73135 & 43.58633 & 4.94 \\
\hline Pz18 & 4.77287 & 43.57821 & 5.03 \\
\hline Pz19 & 4.88876 & 43.52455 & 7.72 \\
\hline Pz2 & 5.01989 & 43.64656 & 60.42 \\
\hline Pz20 & 4.66191 & 43.66107 & 13.47 \\
\hline
\end{tabular}

(continued on next page) 
Appendix B (continued)

\begin{tabular}{|c|c|c|c|}
\hline ID & X (WGS84) & Y (WGS84) & $\mathrm{H}(\mathrm{m}$ asl $)$ \\
\hline Pz21 & 4.72872 & 43.67346 & 22.41 \\
\hline Pz22 & 5.01764 & 43.67794 & 75.87 \\
\hline Pz23 & 5.08365 & 43.67409 & 96.87 \\
\hline Pz24 & 4.68383 & 43.59042 & 1.29 \\
\hline Pz3 & 4.99705 & 43.63864 & 58.58 \\
\hline Pz4 & 4.92472 & 43.64037 & 43.63 \\
\hline Pz5 & 4.87104 & 43.63874 & 34.28 \\
\hline Pz6 & 4.98038 & 43.60436 & 44.53 \\
\hline Pz7 & 4.96885 & 43.55813 & 28.34 \\
\hline Pz8 & 4.96660 & 43.53273 & 21.03 \\
\hline Pz9 & 4.96427 & 43.49161 & 11.91 \\
\hline C3 & 4.81429 & 43.42353 & 0.24 \\
\hline C4 & 4.81985 & 43.42740 & 0.14 \\
\hline IKEA1 & 4.87401 & 43.47474 & 0.60 \\
\hline IKEA2 & 4.87724 & 43.47061 & 0.83 \\
\hline IKEA3 & 4.87960 & 43.47000 & 0.86 \\
\hline IKEA4 & 4.87873 & 43.47876 & 1.09 \\
\hline L1 & 4.80963 & 43.48494 & 0.40 \\
\hline L2 & 4.81597 & 43.47985 & 0.47 \\
\hline L3 & 4.82911 & 43.47132 & 0.38 \\
\hline P13 & 4.89621 & 43.48502 & 2.67 \\
\hline P16bis & 4.82625 & 43.51712 & 0.75 \\
\hline P1901 & 4.81595 & 43.54072 & 1.84 \\
\hline P20 GPMM & 4.83693 & 43.51098 & 0.89 \\
\hline P2171 & 4.81741 & 43.52473 & 1.00 \\
\hline P21bis & 4.80697 & 43.54045 & 1.42 \\
\hline P21 GPMM & 4.80694 & 43.54081 & 1.40 \\
\hline P26bis & 4.82720 & 43.55000 & 1.30 \\
\hline P27 & 4.86015 & 43.54307 & 3.82 \\
\hline P33 & 4.87583 & 43.53384 & 4.24 \\
\hline P33bis & 4.87511 & 43.52956 & 3.53 \\
\hline P34 & 4.89605 & 43.52860 & 11.13 \\
\hline P4 & 4.87830 & 43.48849 & 1.27 \\
\hline P70 & 4.88264 & 43.51321 & 2.48 \\
\hline P72 & 4.88675 & 43.49974 & 2.24 \\
\hline P9 & 4.86126 & 43.50553 & 0.93 \\
\hline PZ15 SPSE & 4.88992 & 43.52959 & 9.69 \\
\hline $\mathrm{X} 15$ & 4.87546 & 43.46448 & 1.46 \\
\hline $\mathrm{X} 17$ & 4.76174 & 43.52408 & 0.49 \\
\hline X19 & 4.78772 & 43.50345 & 0.48 \\
\hline X20bis & 4.82010 & 43.51048 & 0.70 \\
\hline $\mathrm{X} 23$ & 4.73649 & 43.53290 & 0.74 \\
\hline X26bis & 4.83662 & 43.49299 & 0.60 \\
\hline X30 & 4.84779 & 43.47360 & 0.50 \\
\hline X33 & 4.85831 & 43.47708 & 0.52 \\
\hline X35 & 4.85953 & 43.47746 & 0.55 \\
\hline X36 & 4.85775 & 43.47926 & 0.53 \\
\hline $\mathrm{X} 4400 \mathrm{~b}$ & 4.79462 & 43.45242 & -0.58 \\
\hline X4415 & 4.83700 & 43.46471 & 0.36 \\
\hline XAbis & 4.77554 & 43.53690 & 0.61 \\
\hline XBbis & 4.78323 & 43.51391 & 0.50 \\
\hline XCbis & 4.80143 & 43.53058 & 0.89 \\
\hline XDbis & 4.84747 & 43.47493 & 0.53 \\
\hline P48 & 5.06030 & 43.63794 & 66.90 \\
\hline 78 & 5.03198 & 43.65161 & 60.70 \\
\hline 84 & 5.06603 & 43.67676 & 91.45 \\
\hline 96 & 4.88759 & 43.64397 & 37.55 \\
\hline 97 & 4.90196 & 43.66780 & 50.57 \\
\hline $87 b$ & 4.98235 & 43.68671 & 65.64 \\
\hline N14 & 5.08969 & 43.61356 & 58.94 \\
\hline N15b & 5.07053 & 43.61248 & 56.15 \\
\hline
\end{tabular}

Appendix B (continued)

\begin{tabular}{llll}
\hline ID & X (WGS84) & Y (WGS84) & H (m asl) \\
\hline N7 & 5.04386 & 43.66701 & 73.76 \\
N8 & 4.95444 & 43.68067 & 59.58 \\
P4 Eyguiere & 4.98691 & 43.67369 & 64.40 \\
PZ2 Touloubre & 5.06609 & 43.66166 & 79.48 \\
\hline
\end{tabular}

\section{References}

Albinet, M., Bonnet, M., Colomb, E., Cornet, G., 1969. Carte hydrogéologique de la France. 993-1019, Istres-Eyguières, Plaine de la Crau. 1/50000.

Archambault, J., 1950. Note sur le mécanisme hydraulique du seuil de Lamanon Rapport inédit No. R122. BURGEAP.

Berard, P., Daum, J.R., Martin, J.C., 1995. "MARTCRAU”: Actualisation du modèle de la nappe de la Crau Rapport No. R38199. BRGM.

Bouzourra, H., Bouhlila, R., Elango, L., Slama, F., Ouslati, N., 2014. Characterization of mechanisms and processes of groundwater salinization in irrigated coastal area using statistics, GIS, and hydrogeochemical investigations. Environ. Sci. Pollut. Res. 22, 2643-2660. http://dx.doi.org/10.1007/s11356-014-3428-0.

BRGM, 2016. Banque de données du Sous-Sol (BSS) http://infoterre.brgm.fr/.

Colomb, E., Roux, M.R., 1978. La Crau, données nouvelles et interprétations. Géologie Méditerranéenne 5, 303-324.

Courault, D., Hadria, R., Ruget, F., Olioso, A., Duchemin, B., Hagolle, O., Dedieu, G., 2010. Combined use of FORMOSAT-2 images with a crop model for biomass and water monitoring of permanent grassland in Mediterranean region. Hydrol. Earth Syst. Sci. 14, 1731-1744. http://dx.doi.org/10.5194/hess-14-1731-2010.

Cova, R., 1965. Etude Hydrogéologique De La Partie Septentrionale De La Crau Et Des Reliefs De Bordure (Thèse). Université de Montpellier, Montpellier.

Craig, H., 1961. Isotopic variations in meteoric waters. Science 133, 1702-1703.

Dansgaard, W., 1964. Stable isotopes in precipitation. Tellus 16, 436-468. http://dx doi.org/10.1111/j.2153-3490.1964.tb00181.x.

Darling, W.G., Gizaw, B., Arusei, M.K., 1996. Lake-groundwater relationships and fluid-rock interaction in the East African Rift Valley: isotopic evidence. J. Afr Earth Sci. 22, 423-431.

Dellery, B., Durozoy, G., Forkasiewicz, J., Gouvernet, C., Margat, J., 1964. Etude hydrogéologique de la Crau Rapport. BRGM.

Dellery, B., Durozoy, G., Glintzboeckel, C., 1970. Etude des resources hydrologiques et hydrogéologiques du sud-est de la France - Fascicule 12 - La Crau Rapport No. SGN-158-PRC. BRGM.

Deutsch, C.V., Journel, A.G., et al., 1992. Geostatistical Software Library and User's Guide. Oxf. Univ. Press, NY.

Gat, J.R., Gonfiantini, R., 1981. Stable Isotope Hydrology. Deuterium and Oxygen-18 in the Water Cycle. IAEA, Vienna.

Gattacceca, J.C., Vallet-Coulomb, C., Mayer, A., Claude, C., Radakovitch, O., Conchetto, E., Hamelin, B., 2009. Isotopic and geochemical characterization of salinization in the shallow aquifers of a reclaimed subsiding zone: the southern Venice Lagoon coastland. J. Hydrol. 378, 46-61.

GO-13, 2009. MNT 20095 m - DEPT 13. CRIGE-PACA, <http://www.crige-paca.org/>.

Gonçalvès, J., Vallet-Coulomb, C., Petersen, J., Hamelin, B., Deschamps, P., 2015. Declining water budget in a deep regional aquifer assessed by geostatistical simulations of stable isotopes: case study of the Saharan "Continental Intercalaire". J. Hydrol. 531, 821-829.

Gouvernet, C., 1959. Evolution géologique des relations Bas-Rhône/Basse-Durance pendant les temps pliocènes et quaternaires. Ann. Fac. Sci. Marseille 580, $273-$ 279.

Guglielmi, Y., Mudry, J., Blavoux, B., 1998. Estimation of the water balance of alluvial aquifers in region of high isotopic contrast: an example from southeastern France. J. Hydrol. 210, 106-115. http://dx.doi.org/10.1016/S0022-1694(98) 00178-4.

Huneau, F., Dakoure, D., Celle-Jeanton, H., Vitvar, T., Ito, M., Traore, S., Compaore, N. F., Jirakova, H., Le Coustumer, P., 2011. Flow pattern and residence time of groundwater within the south-eastern Taoudeni sedimentary basin (Burkina Faso, Mali). J. Hydrol. 409, 423-439. http://dx.doi.org/10.1016/j. jhydrol.2011.08.043.

IAEA, 2009. Reference Sheet for VSMOW2 and SLAP2 international measurement standards. Int. At. Energy Agency 5.

IAEA/WMO, 2016. GNIP. Global Network for Isotopes in Precipitation <http://www. iaea.org/water>.

Ihaka, R., Gentleman, R., 1996. R: a language for data analysis and graphics. J. Comput. Graph. Stat. 5, 299-314.

Kanarek, A., Michail, M., 1996. Groundwater recharge with municipal effluent: Dan region reclamation project, Israel. Water Sci. Technol. 34, 227-233. http://dx. doi.org/10.1016/S0273-1223(96)00842-6.

Kim, Y., Lee, K.-S., Koh, D.-C., Lee, D.-H., Lee, S.-G., Park, W.-B., Koh, G.-W., Woo, N.C., 2003. Hydrogeochemical and isotopic evidence of groundwater salinization in a coastal aquifer: a case study in Jeju volcanic island, Korea. J. Hydrol. 270, 282-294. http://dx.doi.org/10.1016/S0022-1694(02)00307-4. 
Liu, Y., Yamanaka, T., Zhou, X., Tian, F., Ma, W., 2014. Combined use of tracer approach and numerical simulation to estimate groundwater recharge in an alluvial aquifer system: a case study of Nasunogahara area, central Japan. J. Hydrol. 519 (Part A), 833-847. http://dx.doi.org/10.1016/j.jhydrol.2014.08.017.

Loheide, S.P., Butler, J.J., Gorelick, S.M., 2005. Estimation of groundwater consumption by phreatophytes using diurnal water table fluctuations: a saturated-unsaturated flow assessment. Water Resour. Res. 41.

Mailhol, J.C., Merot, A., 2007. SPFC: a tool to improve water management and hay production in the Crau region. Irrig. Sci. 26, 289-302. http://dx.doi.org/10.1007/ s00271-007-0099-3.

Ma, L., Spalding, R.F., 1996. Stable isotope characterization of the impacts of artificial ground water recharge1. JAWRA - J. Am. Water Resour. Assoc. 32 1273-1282. http://dx.doi.org/10.1111/j.1752-1688.1996.tb03496.x.

McGuire, K.J., DeWalle, D.R., Gburek, W.J., 2002. Evaluation of mean residence time in subsurface waters using oxygen-18 fluctuations during drought conditions in the mid-Appalachians. J. Hydrol. 261, 132-149. http://dx.doi.org/10.1016 S0022-1694(02)00006-9.

Météo-France, 2016. Données publiques climatiques <https://donneespubliques meteofrance.fr $/>$.

Molliex, S., 2010. Caractérisation de la déformation tectonique récente en Provence (Sud-Est France) Thèse. Collège de France.

Olioso, A., Lecerf, R., Baillieux, A., Chanzy, A., Ruget, F., Banton, O., Lecharpentier, P., Trolard, F., Cognard-Plancq, A.-L., 2013. Modelling of drainage and hay production over the Crau aquifer for analysing impact of global change on aquifer recharge. Procedia Environ. Sci. 19, 691-700. http://dx.doi.org/10.1016/ j.proenv.2013.06.078.

Pebesma, E.J., Wesseling, C.G., 1998. Gstat: a program for geostatistical modelling, prediction and simulation. Comput. Geosci. 24, 17-31. http://dx.doi.org/ 10.1016/S0098-3004(97)00082-4.

Plöthner, D., Geyh, M.A., 1991. $\delta^{18} \mathrm{O}$ values as tracer of artificial groundwater recharge downstream of a reservoir. Presented at the IAH, Lausanne, pp. 533539.

Stigter, T.Y., Carvalho Dill, A.M.M., Ribeiro, L., Reis, E., 2006. Impact of the shift from groundwater to surface water irrigation on aquifer dynamics and hydrochemistry in a semi-arid region in the south of Portugal. Agric. Water Manag. 85, 121-132. http://dx.doi.org/10.1016/j.agwat.2006.04.004.

Terrier, M., 1991. Néotectonique De La Provence Occidentale (France): Vers Une Analyse Multicritère Des Déformations Récentes : application À La Classification Des Structures Sismogènes. Editions du BRGM.

Tsang, Y.-P., Hornberger, G., Kaplan, L.A., Newbold, J.D., Aufdenkampe, A.K., 2014. A variable source area for groundwater evapotranspiration: impacts on modeling stream flow. Hydrol. Process. 28, 2439-2450. http://dx.doi.org/10.1002/ hyp.9811.

Williams, A.E., 1997. Stable isotope tracers: natural and anthropogenic recharge, Orange County, California. J. Hydrol. 201, 230-248. http://dx.doi.org/10.1016/ S0022-1694(97)00042-5. 